\title{
Hijab and "Hitchhiking": A Field Study
}

\author{
Farid Pazhoohi ${ }^{1} \cdot$ Robert P. Burriss $^{2}$ (C)
}

Published online: 9 October 2015

(C) Springer International Publishing 2015

\begin{abstract}
In the West, the style of a woman's dress is perceived as a cue to her sexual behavior and influences the likelihood that a man will initiate conversation with the woman or offer her assistance. Hijab, or Islamic veiling, varies in the extent to which it reveals skin and body shape; the style a woman adopts affects her attractiveness to men. To test whether women who wear more liberal or conservative forms of hijab are more likely to be offered help by men, we observed Iranian motorists in a "hitchhiking" situation. Here, we show that a young female confederate, standing beside a road and in view of motorists but not actively soliciting assistance, was more likely to be offered a ride when she wore a headscarf and close-fitting garments (liberal dress) rather than a full body veil (chador, conservative dress). When the woman wore liberal dress, $21.4 \%$ of motorists offered a ride; only $3.9 \%$ of motorists offered a ride to the woman when she wore conservative dress - a significant difference. All drivers were men. This small to medium effect is substantially larger than those reported in similar studies in Europe and extends previous research on male helping behavior and female attractiveness to Iran, a nation where courtship behavior and dress are constrained by stricter social mores and laws than apply in the West.
\end{abstract}

Keywords Altruism $\cdot$ Attraction $\cdot$ Clothing $\cdot$ Hijab $\cdot$ Veiling

Robert P. Burriss

rob@robertburriss.com

1 Shiraz, Iran

2 Department of Psychology, Northumbria University, Newcastle NE1 8ST, UK

\section{Introduction}

How a woman chooses to dress influences how attractive she appears to men. For example, men are more attracted to women who wear red (Roberts, Owen, and Havlíček 2010) or clothing that is tight and reveals skin (Santin 1995). The effects of clothing on attractiveness depend on the type of relationship men seek: clothing that reveals the body increases a woman's attractiveness as a short-term sexual partner but decreases her attractiveness as a marriage partner (Hill, Nocks, and Gardner 1987). This may be because clothing style communicates information about women's mating behaviors and intentions. Grammer, Renninger, and Fischer (2005) found that women who self-reported that they were motivated to attend a nightclub to flirt or to find a partner for sex also tended to wear more semi-transparent clothing. Women make greater efforts to augment their beauty and choose to wear more revealing, fashionable, and red clothing during the fertile phase of the ovulatory cycle (Beall and Tracy 2013; Durante, Li, and Haselton 2008; Haselton, Mortezaie, Pillsworth, Bleske-Rechek, and Frederick 2007), when their sexual desire peaks (e.g., Bullivant et al. 2004; Pillsworth, Haselton, and Buss 2004). Women, especially those who are interested in casual sex, wear clothes that they believe will attract men (Elliot and Pazda 2012; Prokop and Hromada 2013). It is clear that women choose to wear clothing that communicates their mating interests and intentions and that others are sensitive to these cues.

Most studies on human courtship and mate preferences are conducted in the West. Women's freedom to choose their clothing style can be restricted by social pressure or legal sanctions which vary across cultures. In Iran, women are obliged in public to adhere to a dress code based on Islamic rules (hijab) (Zahedi 2008). Hair must be covered; the most common form of head covering is a scarf that is fastened under the chin (referred to as a hijab or roosari), which conceals the 
hair but leaves the face visible. The body must be covered with a loose coat or manteau. The arms must be concealed to the wrists and the legs to the ankles. In practice, some women position the scarf so that their hair is visible and wear clothes that reveal body shape or forearm skin (Moruzzi 2008). In Iran, this style of dress is considered liberal or secular (or "bad hijab"). In holy places, women must wear a chador, a full-length sleeveless cloak worn over the head and held shut in front by the hands. This garment conceals the whole body except for the face and feet. Some women choose to wear a chador at all times when in public, a style of dress considered conservative or religious. It is unclear whether findings from research into clothing and female sexual behavior conducted in the West can be generalized to nonWestern nations such as Iran.

In a recent study, Pazhoohi and Hosseinchari (2014) showed Iranian men photographs of a young woman wearing either a black headscarf and tight black clothing, a black headscarf and loose black clothing, or a chador. Participants viewed the woman for longer when she wore the tight or loose clothing rather than the chador. The woman was rated significantly more attractive when wearing the tight rather than the loose clothing, and when wearing the loose clothing rather than the chador. Iranian men may find women who wear liberal dress more attractive because this style of clothing reveals body shape cues that men find appealing, such as a low waistto-hip ratio (Singh 1993) or because they believe liberal dress signifies a liberal attitude to sex (Goetz, Easton, Lewis, and Buss 2012). Pazhoohi and Hosseinchari (2014) also suggest that women may be encouraged to adopt conservative dress as a form of mate guarding. If so, men may prefer women in liberal dress because approaching these women is less likely to prompt retaliatory violence from male relatives and associates who are motivated to police female sexuality.

Preferences expressed in the laboratory may not reflect mate choice in the real world because, as DeBruine (2005) points out, preferences are unconstrained whereas behavior is a compromise between what is desired and what is available. It is important to conduct more ecologically valid tests of mate preferences, especially when behavior is strongly constrained by social mores and laws, as in Iran. The hitchhiking paradigm offers just such a method of assessing the effect of clothing styles on men's willingness to assist women.

In France, male motorists more frequently stop to offer rides to women who smile, have large breasts and blonde hair, and wear makeup and red clothes (Guéguen 2007, 2012; Guéguen and Fischer-Lokou 2004; Guéguen and Lamy 2009, 2013). Each of these traits, except for large breasts (Dixson, Duncan, and Dixson 2015; Dixson et al. 2011; Swami and Tovée 2013), has been shown to be attractive in laboratory studies (Golle, Mast, and Lobmaier 2014; Janif, Brooks, and Dixson 2015; Mulhern, Fieldman, Hussey, Lévêque, and Pineau 2003; Roberts, et al. 2010). Hitchhiking as it is practiced in the West is unfamiliar in Iran, although informal taxi services are common. Informal taxi drivers (known as mosafer kesh) drive through areas where they expect to encounter persons seeking transport. They either respond to verbal requests for a ride or solicit passengers by stopping and offering a ride. Men who do not explicitly identify as informal taxi drivers may also offer rides without expecting payment. One benefit of this activity for male drivers may be that it facilitates unsupervised social interactions with women.

Because Iranian men find women more attractive if they dress in a more liberal style (Pazhoohi and Hosseinchari 2014), we predicted that motorists in Iran would more frequently offer a ride to a woman wearing liberal rather than conservative dress.

\section{Method}

\section{Procedure}

We conducted a field experiment on a street near to a shopping mall in Shiraz, Iran (see Fig. 1). We selected this location because the street is straight and well lit, and traffic passes at a slow speed. A person standing beside this street is visible to motorists. A 25-year-old woman acted as a confederate. She stood beside the street from 20:00 on Monday nights in two consecutive weeks in spring. A male observer stood $15 \mathrm{~m}$ behind the confederate, where he could record data and intervene if necessary (at no time did the confederate require assistance).

On the first night, the confederate wore a black hijab headscarf covering her hair, neck, and shoulders and black tight clothing that covered her skin while revealing body shape (liberal clothing). On the second night, the confederate wore a black chador that covered her whole body except for her face (conservative clothing). On neither occasion did the confederate wear makeup (see Fig. 2).

The confederate did not signal that she desired a ride and was instructed not to seek eye contact with motorists. The

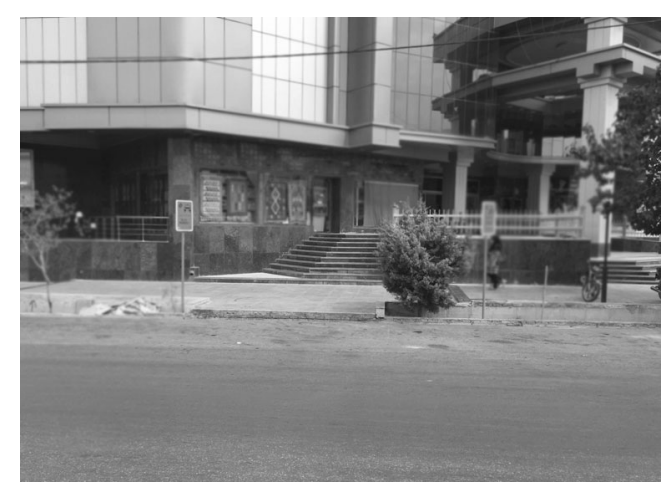

Fig. 1 The location where the experiment took place. The confederate stood in the street approximately in the center of the scene. The observer stood on the steps behind 


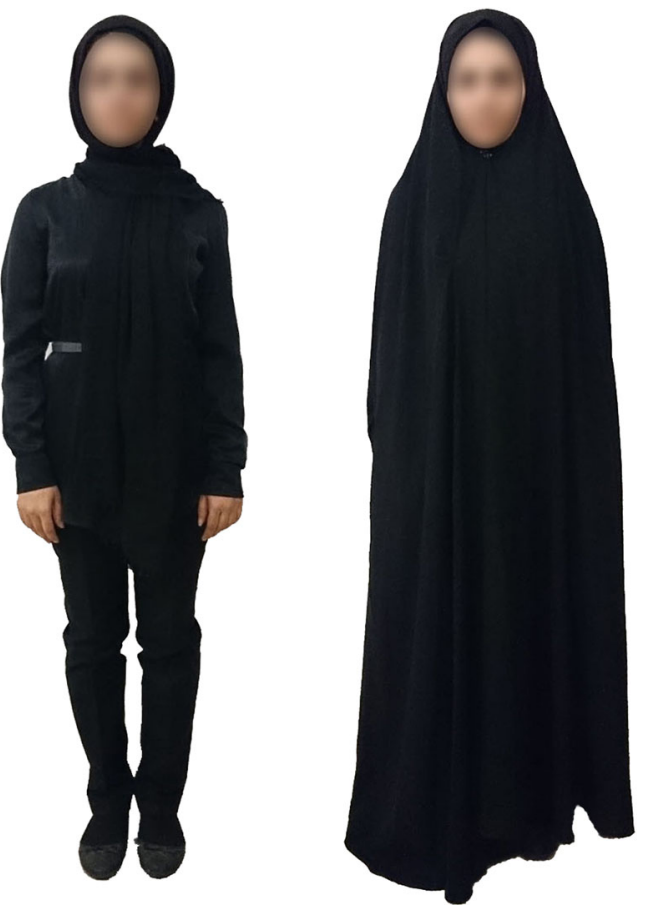

Fig. 2 The outfits worn by the confederate. Left, the liberal outfit (headscarf and tight clothing); right, the conservative outfit (chador)

observer recorded the number of motorists who passed and who stopped to offer the confederate a ride. When the confederate was offered a ride, she thanked the motorist and explained that she was waiting for her fiancé to pick her up. She also noted the sex of the motorist (all motorists who stopped were males). It was not possible to note the sex of passing motorists. When a motorist stopped to offer a ride, the observer stopped counting the passing cars. He resumed counting once the motorist pulled away. When 1000 cars had either passed by or stopped, the experiment ended. On both days, this took no more than $2 \mathrm{~h}$.

We did not count offers from licensed taxi drivers (identifiable by their yellow taxicabs).

\section{Participants}

Two thousand anonymous motorists acted as participants. All motorists who stopped were men. We did not collect additional data on the motorists. Of all men working in the Iranian informal sector, which includes informal taxi drivers, $44.4 \%$ have secondary education and $7.8 \%$ some college education (Bahramitash 2013).

\section{Results}

Of the 2000 motorists, $253(12.65 \%)$ stopped to offer the confederate a ride. When the confederate wore liberal clothing, 214 motorists offered her a ride; when she wore conservative clothing, only 39 motorists stopped. We analyzed our data using a chi-square test and found that motorists were significantly more likely to offer the confederate a ride when she wore liberal rather than conservative dress, $\chi^{2}(1$, $N=2000)=138.58, p<0.001, \varphi=0.26$, odds ratio $=6.71$.

We also calculated odds ratios for five studies by Guéguen and colleagues on the effects of female appearance on the helping behavior of male motorists (see Table 1). Where Guéguen tested the effects of variables with more than two levels (Guéguen 2007, 2012; Guéguen and Lamy 2009), we present data for the levels between which the difference was greatest, so as to make the odds ratios easier to interpret. For example, Guéguen (2012) found that the largest percentage of male motorists $(20.77 \%)$ offered a ride to a woman wearing red and the smallest percentage (12.48 \%) to a woman wearing black. By excluding trials in which the confederate wore white, yellow, blue, and green clothing, we see that male motorists were 1.66 times more likely to offer a ride to a woman in red rather than black. The strongest effect of an aspect of female appearance on male helping behavior in the hitchhiking paradigm thus far identified by Guéguen and colleagues is that of smiling: women who smile are twice as likely to be offered a ride as women who do not smile. The effect that we identify of liberal versus conservative Islamic dress is much stronger: a woman wearing liberal dress is 6.71 times more likely to be offered a ride than the same woman wearing conservative dress.

\section{Discussion}

Iranian motorists were more likely to offer a woman a ride if she wore liberal rather than conservative dress, supporting our hypothesis. This result is consistent with evidence from a laboratory-based study that shows Iranian men find women more attractive if they wear less veiling (Pazhoohi and Hosseinchari 2014).

We identified an effect that was small to moderate in size, though much larger than the effects reported in similar hitchhiking studies in France (Guéguen 2007, 2012; Guéguen and Fischer-Lokou 2004; Guéguen and Lamy 2009, 2013). Why is our effect so much larger? Liberal and conservative Iranian styles of dress differ more conspicuously than many of the traits investigated by Guéguen and colleagues, and so Iranian motorists may more readily detect the visual difference between a woman wearing liberal and conservative Islamic dress than their French peers would the visual difference between a smiling and a non-smiling woman (although the difference between red and black clothing may well be more noticeable). It is also possible that the conservativeness of an Iranian woman's dress more strongly influences her attractiveness or is perceived to signal her sexual availability to a greater extent, than, say, European women's hair color (Guéguen 2012). 
Table 1 Summary of effect sizes in hitchhiking studies

\begin{tabular}{|c|c|c|c|c|c|}
\hline Study & Variable & Number $(N)$ & $\chi^{2}$ & $\varphi$ & Odds ratio \\
\hline Guéguen and Fischer-Lokou 2004 & Smile/no smile ${ }^{\mathrm{a}}$ & 400 & 5.82 & 0.12 & 2.00 \\
\hline Guéguen 2007 & $\mathrm{C}$ cup/A cup bust ${ }^{\mathrm{b}}$ & $518^{\mathrm{c}}$ & 6.83 & 0.11 & 1.80 \\
\hline Guéguen and Lamy 2009 & Blond/black hair ${ }^{\mathrm{d}}$ & $1004^{\mathrm{c}}$ & 6.94 & 0.08 & 1.55 \\
\hline Guéguen 2012 & Red/black clothing ${ }^{\mathrm{e}}$ & $1176^{\mathrm{c}}$ & 8.99 & 0.09 & 1.66 \\
\hline Guéguen and Lamy 2013 & Makeup/no makeup & $959^{\mathrm{c}}$ & 12.34 & 0.11 & 1.78 \\
\hline Current study & Liberal/conservative Islamic dress & 2000 & 138.58 & 0.26 & 6.71 \\
\hline
\end{tabular}

${ }^{a}$ Study used male and female confederates; the analysis reported here excludes male confederates

${ }^{\mathrm{b}}$ Study tested for differences between A, B, and C cups; here, we test for the difference between A and C cup, which is the largest difference

${ }^{\mathrm{c}}$ Participants included male and female motorists; the analysis reported here excludes female motorists

${ }^{\mathrm{d}}$ Study tested for differences between blond, brown, and black hair; here, we test for the difference between blond and black hair, which is the largest difference

${ }^{\mathrm{e}}$ Study tested for the differences between black, white, red, yellow, blue, and green clothing; here, we test for the difference between red and black clothing, which is the largest difference

We note that it is common in Iranian cities for young women to wear visible makeup, colorful fabrics, and loose headscarves that reveal head hair (Moruzzi 2008). Therefore, our participants are unlikely to have seen the liberal outfit worn by the confederate as unusually immodest within the range of styles they encounter. We had the confederate wear all black clothing in both conditions to ensure that she was equally conspicuous. If the confederate were to adopt an even more liberal costume, we would predict that more motorists would stop to offer her a ride, either because brighter clothing is more conspicuous or because colorful clothing and loose headscarves are perceived as stronger cues to a woman's immodesty, promiscuity, or sexual exploitability (sensu Goetz et al. 2012). The real effect of liberal clothing on male helping behavior in Iran may be somewhat larger than the effect we describe here, a possibility that could be tested in future studies.

Men are more likely to offer help to women they find attractive, and differences in clothing are sufficient to drive this effect. Men rate women who wear high-heeled shoes more attractive (Morris, White, Morrison, and Fisher 2013), and Guéguen (2015) has found that men are more likely to grant a woman's request for assistance, and to offer unsolicited assistance, when that woman wears high-heeled shoes rather than flats. This may be because certain styles of female dress, including high heels or revealing clothing, are perceived as cues to a woman's sexual interest or behavior. Studies in the USA show that women who wear revealing and tight clothing are perceived to be more sexually exploitable and more attractive for short-term, but not long-term, relationships (Goetz, Easton, and Buss 2014; Goetz, et al. 2012) and that women who are more inclined toward casual sex report efforts to attract men using tactics that signal their sexual exploitability, which include wearing revealing and tight clothing (Goetz, et al. 2014). North American and Indian young adults assign greater blame to female victims of sexual assault who dress "provocatively" (Cassidy and Hurrell 1995; Kanekar and Kolsawalla 1980), indicating that they feel it is more morally acceptable to sexually exploit women who wear revealing clothes. Also, although men value a lack of sexual experience in a partner (a preference which is stronger in Iran than in France and other Northern European nations, Buss 1989), there are circumstances under which men are attracted to cues of apparent promiscuity. Men rate line drawings of women with tattoos as more promiscuous and less attractive (Swami and Furnham 2007) but are more likely to initiate conversation with tattooed women whom they encounter in a naturalistic environment (e.g., a beach) and think it more likely that a woman with tattoos will consent to sex on a first date (Guéguen 2013). Furthermore, when men judge women's attractiveness specifically for a short-term relationship, they rate as more attractive those women who appear to be promiscuous (Röder, Weege, Carbon, Shackelford, and Fink 2015), and there is evidence that men are accurate in their judgments of female sexual faithfulness from appearance alone (Leivers, Simmons, and Rhodes 2015). It is possible, therefore, that Iranian men interpret liberal dress as advertising liberal attitudes to sexual relationships and judge it easier or more morally acceptable to approach women whose hijab is less conservative. This, as well as men's greater attraction to women who wear less veiling, could explain why our participants more frequently offered assistance to the confederate when she wore liberal dress.

Studies have shown that women are rated more attractive when they wear attractive clothes, even when ratings are based on photographs of women adopting neutral facial expressions and clothing is not visible (Lõhmus, Sundström, and Björklund 2009; Roberts, et al. 2010). These effects are likely driven by micro-expressions or changes in head posture, which are known to influence attractiveness (Burke and Sulikowski 2010; Sulikowski, Burke, Havlíček, and Roberts 
2015). Although we instructed the confederate to behave identically regardless of the clothes she wore, it is possible that any unconscious changes in behavior influenced the motorists' willingness to offer a ride. However, because any differences in the confederate's behavior were likely far less salient than the differences in her costume, particularly under the circumstances in which she was viewed by the motorists, we suspect that changes in behavior present only a minor confound. We also note that clothing styles are associated with certain postures (the chador restricts arm and head movement) and that style and posture are difficult to separate.

Our results extend the findings of previous studies in Europe and North America on male helping behavior and female attractiveness to Iran, a nation where courtship behavior and dress are constrained by stricter social mores and laws than apply in the West. Future research could explore whether female dress influences helping behavior under other conditions, perhaps in environments where men seek long-term partners or where the sexual intent of men's behavior is less ambiguous. We note that in the USA, persons who regularly attend religious services are more likely to hold restricted attitudes to sex and to report fewer sexual partners (Weeden, Cohen, and Kenrick 2008). Iranian men with a restricted sociosexuality or who seek a partner for marriage may prefer women who dress conservatively, if they interpret conservative dress as an indicator of religiosity. It would also be interesting to test whether Iranian women, or culturally Muslim women living in the West, adopt styles of dress that align with their sexual strategies or to advertise their desire for long- or short-term relationship partners, as do North American women (Goetz et al. 2014).

Acknowledgments RPB is supported by an Anniversary Research Fellowship at Northumbria University. The authors thank the confederate for her valuable assistance.

\section{References}

Bahramitash, R. (2013). Gender and entrepreneurship in Iran: microenterprise and the informal sector. New York: Palgrave Macmillan.

Beall, A. T., \& Tracy, J. L. (2013). Women more likely to wear red or pink at peak fertility. Psychological Science, 24, 1837-1841. doi:10. 1177/0956797613476045.

Bullivant, S. B., Sellergren, S. A., Stern, K., Spencer, N. A., Jacob, S., Mennella, J. A., \& McClintock, M. K. (2004). Women's sexual experience during the menstrual cycle: identification of the sexual phase by noninvasive measurement of luteinizing hormone. Journal of Sex Research, 41, 82-93.

Burke, D., \& Sulikowski, D. (2010). A new viewpoint on the evolution of sexually dimorphic human faces. Evolutionary Psychology, 8 , 147470491000800404. doi:10.1177/147470491000800404.

Buss, D. M. (1989). Sex differences in human mate preferences: evolutionary hypotheses tested in 37 cultures. Behavioral and Brain Sciences, 12, 1-14. doi:10.1017/S0140525X00023992.
Cassidy, L., \& Hurrell, R. M. (1995). The influence of victims' attire on adolescents' judgments of date rape. Adolescence, 30, 319-323.

De Bruine, L. M. (2005). Trustworthy but not lust-worthy: contextspecific effects of facial resemblance. Proceedings of the Royal Society B: Biological Sciences, 272, 919-922. doi:10.1098/rspb. 2004.3003.

Dixson, B. J., Vasey, P. L., Sagata, K., Sibanda, N., Linklater, W. L., \& Dixson, A. F. (2011). Men's preferences for women's breast morphology in New Zealand, Samoa, and Papua New Guinea. Archives of Sexual Behavior, 40, 1271-1279. doi:10.1007/s10508-010-9680-6.

Dixson, B. J., Duncan, M., \& Dixson, A. F. (2015). The role of breast size and areolar pigmentation in perceptions of women's sexual attractiveness, reproductive health, sexual maturity, maternal nurturing abilities, and age. Archives of Sexual Behavior, 44, 1685-1695. doi:10.1007/s10508-015-0516-2.

Durante, K. M., Li, N. P., \& Haselton, M. G. (2008). Changes in women's choice of dress across the ovulatory cycle: naturalistic and laboratory task-based evidence. Personality and Social Psychology Bulletin, 34, 1451-1460. doi:10.1177/0146167208323103.

Elliot, A. J., \& Pazda, A. D. (2012). Dressed for sex: red as a female sexual signal in humans. PloS One, 7, e34607. doi:10.1371/journal. pone. 0034607 .

Goetz, C. D., Easton, J. A., Lewis, D. M. G., \& Buss, D. M. (2012). Sexual exploitability: observable cues and their link to sexual attraction. Evolution and Human Behavior, 33, 417-426. doi:10.1016/j. evolhumbehav.2011.12.004.

Goetz, C. D., Easton, J. A., \& Buss, D. M. (2014). Women's perceptions of sexual exploitability cues and their link to sexual attractiveness. Archives of Sexual Behavior, 43, 999-1008. doi:10.1007/s10508013-0188-8.

Golle, J., Mast, F. W., \& Lobmaier, J. S. (2014). Something to smile about: the interrelationship between attractiveness and emotional expression. Cognition and Emotion, 28, 298-310. doi:10.1080/ 02699931.2013.817383.

Grammer, K., Renninger, L., \& Fischer, B. (2005). Disco clothing, female sexual motivation, and relationship status: is she dressed to impress? Journal of Sex Research, 41, 66-74. doi:10.1080/ 00224490409552214.

Guéguen, N. (2007). Bust size and hitchhiking: a field study. Perceptual and Motor Skills, 105, 1294-1298. doi:10.2466/pms.105.4.12941298.

Guéguen, N. (2012). Color and women hitchhikers' attractiveness: gentlemen drivers prefer red. Color Research and Application, 37, 7678. doi: $10.1002 / \mathrm{col} .20651$.

Guéguen, N. (2013). Effects of a tattoo on men's behavior and attitudes towards women: an experimental field study. Archives of Sexual Behavior, 42, 1517-1524. doi:10.1007/s10508-013-0104-2.

Guéguen, N. (2015). High heels increase women's attractiveness. Archives of Sexual Behavior. doi:10.1007/s10508-014-0422-z.

Guéguen, N., \& Fischer-Lokou, J. (2004). Hitchhikers' smiles and receipt of help. Psychological Reports, 94, 756-760. doi:10.2466/pr0.94.3. 756-760.

Guéguen, N., \& Lamy, L. (2009). Hitchhiking women's hair color. Perceptual and Motor Skills, 109, 941-948. doi:10.2466/pms.109. 3.941-948.

Guéguen, N., \& Lamy, L. (2013). The effect of facial makeup on the frequency of drivers stopping for hitchhikers. Psychological Reports, 113, 97-101. doi:10.2466/17.07.PR0.113x12z5.

Haselton, M. G., Mortezaie, M., Pillsworth, E. G., Bleske-Rechek, A. L., $\&$ Frederick, D. A. (2007). Ovulatory shifts in human female ornamentation: near ovulation, women dress to impress. Hormones and Behavior, 51, 40-45. doi:10.1016/j.yhbeh.2006.07.007.

Hill, E. M., Nocks, E. S., \& Gardner, L. (1987). Physical attractiveness: manipulation by physique and status displays. Ethology and Sociobiology, 8, 143-154. doi:10.1016/0162-3095(87)90037-9. 
Janif, Z. J., Brooks, R. C., \& Dixson, B. J. (2015). Are preferences for women's hair color frequency-dependent? Adaptive Human Behavior and Physiology, 1, 54-71. doi:10.1007/s40750-0140008-y.

Kanekar, S., \& Kolsawalla, M. B. (1980). Responsibility of a rape victim in relation to her respectability, attractiveness, and provocativeness. Journal of Social Psychology, 112, 153-154. doi:10.1080/ 00224545.1980.9924310.

Leivers, S., Simmons, L. W., \& Rhodes, G. (2015). Men's sexual faithfulness judgments may contain a kernel of truth. PloS One, 10, e0134007. doi:10.1371/journal.pone.0134007.

Lõhmus, M., Sundström, L. F., \& Björklund, M. (2009). Dress for success: human facial expressions are important signals of emotions. Annales Zoologici Fennici, 46, 75-80. doi:10.5735/086.046.0108.

Morris, P. H., White, J., Morrison, E. R., \& Fisher, K. (2013). High heels as supernormal stimuli: how wearing high heels affects judgements of female attractiveness. Evolution and Human Behavior, 34, 176 181. doi:10.1016/j.evolhumbehav.2012.11.006.

Moruzzi, N. C. (2008). Trying to look different: Hijab as the selfpresentation of social distinctions. Comparative Studies of South Asia, Africa and the Middle East, 28, 225-234. doi:10.1215/ 1089201x-2008-001.

Mulhern, R., Fieldman, G., Hussey, T., Lévêque, J. L., \& Pineau, P. (2003). Do cosmetics enhance female Caucasian facial attractiveness? International Journal of Cosmetic Science, 25, 199-205. doi:10.1046/j.1467-2494.2003.00188.x.

Pazhoohi, F., \& Hosseinchari, M. (2014). Effects of religious veiling on Muslim men's attractiveness ratings of Muslim women. Archives of Sexual Behavior, 43, 1083-1086. doi:10.1007/s10508-014-0259-5.

Pillsworth, E. G., Haselton, M. G., \& Buss, D. M. (2004). Ovulatory shifts in female sexual desire. Journal of Sex Research, 41, 55-65. doi:10.1080/00224490409552213.
Prokop, P., \& Hromada, M. (2013). Women use red in order to attract mates. Ethology, 119, 605-613. doi:10.1111/eth.12102.

Roberts, S. C., Owen, R. C., \& Havlíček, J. (2010). Distinguishing between perceiver and wearer effects in clothing color-associated attributions. Evolutionary Psychology, 8, 147470491000800304. doi: 10.1177/147470491000800304.

Röder, S., Weege, B., Carbon, C.-C., Shackelford, T. K., \& Fink, B. (2015). Men's perception of women's dance movements depends on mating context, but not men's sociosexual orientation. Personality and Individual Differences, 86, 172-175. doi:10.1016/ j.paid.2015.06.020.

Santin, E. (1995). Impression-management: die Wirkung von Kleidung. Universität Wien.

Singh, D. (1993). Adaptive significance of female physical attractiveness: role of waist-to-hip ratio. Journal of Personality and Social Psychology, 65, 293-307. doi:10.1037/0022-3514.65.2.293.

Sulikowski, D., Burke, D., Havlíček, J., \& Roberts, S. C. (2015). Head tilt and fertility contribute to different aspects of female facial attractiveness. Ethology, 121, 1002-1009. doi:10.1111/eth.12412.

Swami, V., \& Furnham, A. (2007). Unattractive, promiscuous, and heavy drinkers: perceptions of women with tattoos. Body Image, 4, 343352. doi:10.1016/j.bodyim.2007.06.005.

Swami, V., \& Tovée, M. J. (2013). Men's oppressive beliefs predict their breast size preferences in women. Archives of Sexual Behavior, 42, 1199-1207. doi:10.1007/s10508-013-0081-5.

Weeden, J., Cohen, A. B., \& Kenrick, D. T. (2008). Religious attendance as reproductive support. Evolution and Human Behavior, 29, 327 334. doi:10.1016/j. evolhumbehav.2008.03.004.

Zahedi, A. (2008). Concealing and revealing female hair: veiling dynamics in contemporary Iran. In J. Heath (Ed.), The veil: women writers on its history, lore, and politics (pp. 250-265). Berkeley: University of California Press. 